\title{
EXPERIMENTAL STUDY OF THE CHARACTERISTICS OF PHOTORESISTS
}

\section{ЕКСПЕРИМЕНТАЛЬНЕ ДОСЛІДЖЕННЯ ХАРАКТЕРИСТИК ФОТООПОРІВ}

Gennadiy SHYSHKIN, Doctor of Pedagogical Sciences, Геннадій ШИшКІн, доктор педагогічних наук, доцент

Associate Professor

https://orcid.org/0000-0003-2617-6699

ur3qugs@gmail.com

\section{Sergey BANDUROV,}

Postgraduate student
Сергій БАНДУРОВ, аспірант

https://orcid.org/0000-0003-0377-985X

Daria BLYZNYUK, sbandurov91@gmail.com student

Berdiansk State Pedagogical University

4 Schmidta St., Berdiansk, Zaporizhzhia region, 71100
Дар'я БЛИЗНюк,

студентка

Бердянський державний педагогічний університет

вул. Шмідта 4, м. Бердянськ, Запорізька обл., 71100

\section{ABSTRACT}

Original manuscript received: October 14, 2019

Revised manuscript accepted: December 12, 2019

The article describes the experimental study of the basic characteristics and parameters of semiconductor photo resistances by students of physics at the Pedagogical University. The study was conducted at a laboratory stand developed, patented and manufactured by us. One of the main components of the professional training of future physics teachers is the formation of skills for organizing and conducting a physical experiment, among them acquiring new knowledge; forming the primary skills of using physical equipment and devices; acquiring the ability to plan the experiment and analyze the results. Our studies have shown that performing only laboratory work according to the prepared instructions, do not yet provide adequate preparation for independent planning and conducting experimental research by students. In order to partially solve the problem of improvement the forms and methods of organizing the initial experiment, we have proposed a pilot work that can be done in the final stage of specialist training.

The purpose of the article is to analyze the results of the study of the photographic resistance characteristics that was offered to students. Studies in which was used photoresist, based on sulfur cadmium included: taking of current voltage, light, spectral and frequency characteristics of photo-resists; determination of integral sensitivity of photo-resistance; determining the influence of external factors on the characteristics of semiconductors. Students studied photographic resistance before and after treatment of its working surface with high-energy electron fluxes with a maximum energy of up to $1.15 \mathrm{MeV}$ to identify the influence of external factors on the characteristics and parameters of semiconductors. The semiconductor was irradiated 
Серія: Педагогічні науки. - Вип.3. - Бердянськ : БДПУ, 2019. - 453 с.

with electrons on an industrial electron accelerator.

Involvement of students in experimental work conducted during extracurricular time and under the guidance of the teacher is essential in generalizing generic experimental research skills of future specialists.

Key words: physical experiment, semiconductor, photo-resistance, properties.

Вступ. Невід'ємним складником процесу підготовки майбутніх учителів фізики $€$ формування в них умінь і навичок проведення самостійних дослідження об'єктів техніки і фрізичних процесів. Навички проведення експериментальних досліджень формуються при виконанні студентами лабораторних і курсових робіт. Навчальний лабораторний експеримент одночасно виступає як метод і засіб навчання. У процесі виконання лабораторної роботи студенти набувають нових знань, перевіряють фрізичні теорії, закони, формують практичні навички проведення експериментальних досліджень. Одним з головних завдань лабораторних робіт $€$ практична підготовка студентів-фізиків до планування і проведення самостійного експериментального дослідження. Однак, як показує практика, проведення лабораторних робіт за традиційною методикою ще не розв'язує повністю цю проблему, а потребує вдосконалення форм і методів планування, організації і проведення фізичного експерименту, обробки і аналізу отриманих результатів.

Для часткового розв'язання цієї проблеми нами запропонована експериментальна робота 3 дослідження характеристик напівпровідникових фотоопорів. Студентам було запропоновано визначити залежності вольт-амперних характеристик від довжини хвилі та інтенсивності світла, впливу потоків електронів високої енергії на характеристики напівпровідників. Робота має практичне значення, і дослідження проводилося на спеціально розробленому для цього стенді.

Проблема вдосконалення експериментальних методів навчання студентів-фрізиків педагогічних університетів завжди викликала увагу 3 боку методистів та науковців. Питанням удосконалення змісту та методів організації та проведення навчального фрізичного експерименту присвячені праці С. Величка, С. Гончаренка, А. Давиденка, Є. Коршака, О. Ляшенка, М. Мартинюка, В. Тищука; проблемі залучення студентів до пізнавальної, дослідницької діяльності присвячені праці П. Атаманчука, Л. Благодаренко, А. Касперського, В. Сергієнка, М. Шута та ін.

Проблема активізації навчально-пізнавальної діяльності студентів фізичних спеціальностей на сучасному етапі розвитку освіти $€$ досить актуальною. Одним з дієвих методів активізації їх пізнавальної діяльності $€$ залучення до експериментальної роботи. Відсутність навичок планування та проведення експерименту суттєво впливає на рівень мотивації студентів до вивчення фізики. За результатами нашого дослідження, 46\% студенів педагогічних університетів не проводили самостійного експерименту в процесі навчання в школі. Досвід роботи в педагогічному університеті показав, що найбільш ефективним методом залучення студентів до активної експериментальної роботи $€$ спільна діяльність з викладачем. Результатом такої роботи може бути удосконалення або створення нових фрізичних приладів, які 3 успіхом можуть використовуватися в 
лабораторному практикумі з фізики [Зикова, 2018]. Метою статmі є розробка методики залучення студентів до самостійної дослідницької діяльності шляхом експериментального вивчення властивостей напівпровідників, залежності провідності фотоопорів від інтенсивності освітлення та довжини хвилі світла, впливу обробки напівпровідника потоком електронів з високою енергією на його характеристики.

Методи та методика дослідження. 3 метою формування дослідницьких експериментальних навичок та залучення студентів до активної пізнавальної діяльності нами запропоновано комплексну роботу 3 вивчення напівпровідникових фотоопорів. Дослідження включали: зняття вольт-амперних, світлових, спектральних та частотних характеристики фотоопорів; визначення інтегральної чутливості фоотоопору; питомої чутливості; кратність зміни опору. Для дослідження використовували фотоопір на основі сірчистого кадмію. 3 метою виявлення впливу зовнішніх факторів на характеристики й параметри напівпровідників студентам пропонували дослідити фотоопори після обробки їх робочих поверхонь потоками електронів 3 максимальною енергією до 1,15 MeВ. Напівпровідник обробляли на промисловому прискорювачі електронів серії ЕЛВ-1 промислового підприємства "Азовська кабельна компанія".

Дослідження проводили на експериментальному стенді (рис. 1), для проведення лабораторних робіт з фізики та радіоелектроніки, який був нами розроблений та запатентований [Федоренко, 2013]. До складу стенду входив світлодіодний блок, у якому розміщено 9 світлодіодів: білого, інфррачервоного, синього, жовтого, зеленого та червоного кольорів випромінювання. Усі світлодіоди марки AL307. У блоці також розміщене універсальне гніздо “СФ" (рис. 1) для встановлення фотоопору, що досліджується. Від зовнішнього світлового потоку зразок захищено кришкою.

За допомогою перемикача SA1 (рис. 1) можна вмикати будь-яку групу світлодіодів. У першому положенні через резистор $\mathrm{R}_{1}$ вмикається світлодіод HL1 білого випромінювання. Він створює на поверхні фотоопору освітленість 20 лк. У другому положенні вмикаються два світлодіоди HL1 і HL2, які забезпечують освітленість F = 40 лк, у третьому $-\mathrm{F}=60$ лк і у четвертому $-\mathrm{F}=80$ лк. Можливість зміни освітленості поверхні фотоопору дозволила побудувати світлові й вольт-амперні характеристики напівпровідника, який досліджується. Почергове підключення світлодіодів різного кольору (різної довжини хвилі) випромінювання дозволяє побудувати спектральні характеристики напівпровідників [Шишкін, 2011; Shyshkin, 2013].

Схема приладу живиться від двох стабілізованих джерел напруги. Одне джерело живиться від обмотки II трансформатора (U ₹ 6,5 B). Після випрямлення напруга стабілізується параметричним стабілізатором R16 - VD5.

Друге джерело з напругою $U \approx 60$ В живиться від обмотки III трансформатора, випрямлюється діодами VD6 - VD9 і стабілізується колом R12 - VD10. 


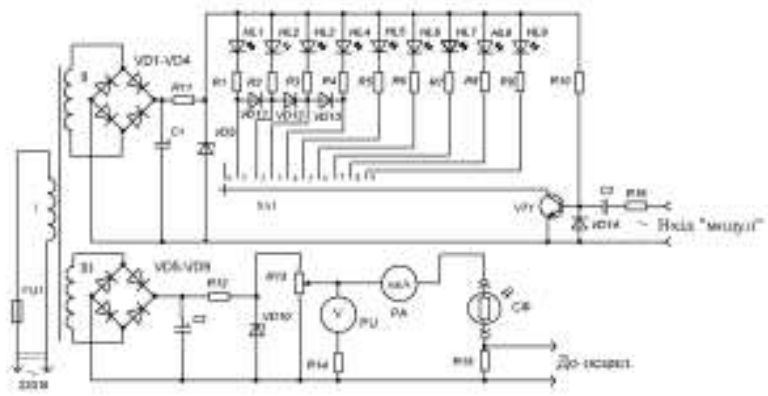

Рис. 1. Принципова схема стенда

Для формування навичок проведення досліджень ми пропонували студентам дослідити властивості та характеристики фотоопору типу ФД-1.

Результати та дискусії. Дослідницька робота проводилася в декілька етапів. На першому етапі студенти досліджували темнові властивості фоотоопорів даного типу. Для зняття вольт-амперної характеристики I=f(U) без освітлення напівпровідника в гніздо “СФ" стенду встановлюють фротоопір, що досліджується. Для запобігання доступу зовнішнього світлового потоку кришка світлодіодного блока стенду закрита. Перемикач SA1 (рис. 1) знаходиться в положення, при якому всі світлодіоди знеструмлені. Напругу, що подається на фотоопір, змінювали від 0 до 50 В за допомогою потенціометра $R_{13}$. Величину струму контролювали мікроамперметром РА. Значення опору $\left(R_{m}\right)$ визначається за кутом нахилу $\left(\operatorname{ctg}\right.$ y) вольт-амперної характеристики. Ураховуючи те, що опір $R_{m}$ вимірюється десятками МОм, то найкраще його обчислити при напрузі $50 \mathrm{~B}$.

На другому етапі дослідження студентам пропонували визначити воль-амперні характеристики при різних значеннях світлового потоку (20 лм, 40 лм, 60 лм, 80 лм). Перемикач SA1 послідовно встановлювали в положення 1, 2, 3, 4 (рис. 1). При цьому вмикалася відповідна група світлодіодів АЛ 307 . Для кожного положення перемикача, змінюючи резистором $R_{13}$ величину напруги від нуля до 50 В, що подається на зразок, знімали вольт-амперні характеристики. Результати досліджень подані на рисунку 2.

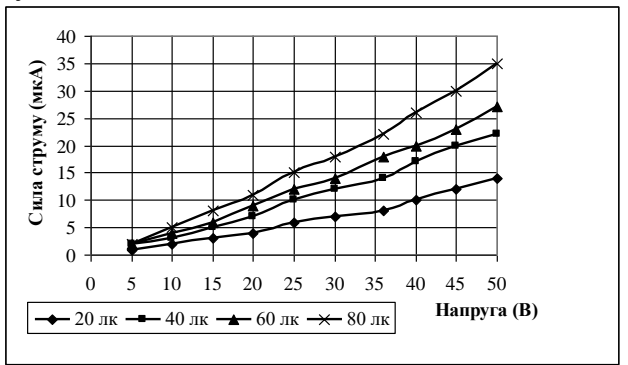

Рис. 2. Залежність силу струму від освітленості та напруги 
Обробки робочої поверхні зразка потоком швидких електронів призвели до зміни вольт-амперних характеристик напівпровідника. Зразок опромінювали електронами 3 енергією $E=1,15 \mathrm{MeB}$ та дозою $55,9 \cdot 10^{2}$ Гр. Результати дослідження відображені на рисунку 3.

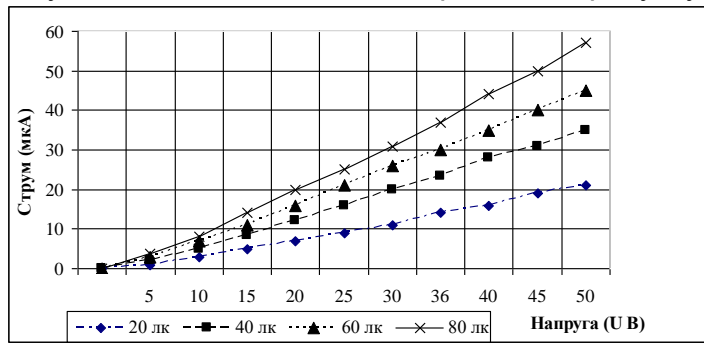

Рис. 3. Залежність силу струму від освітленості та напруги після опромінювання потоком швидких електронів

Аналіз вольт-амперних характеристик вказує на вплив опромінювання на провідність напівпровідника. Для визначення залежності провідності напівпровідників від інтенсивності світлового потоку зі сталим спектральним складником $\rho=f(E)$, що падає на робочу поверхню фоотоопору, використовували графріки залежностей сили струму від напруги (рис. 2 і 3). Для значення напруги $U=30$ В студентам пропонували розрахувати провідності для всіх значень світлового потоку (20 лм, 40 лм, 60 лм, 80 лм) та побудувати графіки. Залежність провідності напівпровідника від інтенсивності освітлення до і після опромінювання потоком електронів для фіксованих значень напруг показано на рис. 4.

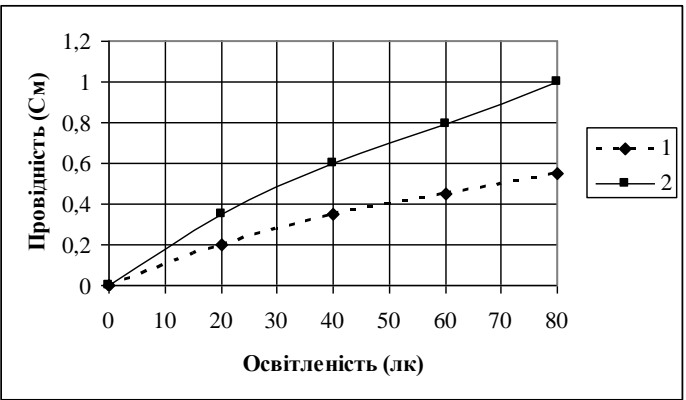

Рис. 4. Залежність провідності від світлового потоку (1 - до опромінювання зразка, 2 - після опромінювання)

Результати дослідження вказують на те, що опромінювання фотоопору ФД-1 потоком електронів значно збільшує провідність напівпровідників цого типу. На наступному етапі дослідження студентам пропонували визначити залежність силу струму від напруги в напівпровіднику для різних значень довжин хвиль світлового потоку, що освітлює зразок.

Спектральна характеристика напівпровідника показує залежність 
Серія: Педагогічні науки. - Вип.3. - Бердянськ : БДПУ, 2019. - 453 с.

чутливості приладу від довжини хвилі світла, що освітлює фотоопір. Вона визначається матеріалом, що використовується для виготовлення світлочутливого елемента. Сірчисто-кадмієві фотоопори мають високу чутливість у видимій області спектра, селенисто-кадмієві - у червоній, а сірчисто-свинцеві - в інфррачервоній.

Для отримання характеристик фотоопір, що досліджується, освітлюється світлом певної довжини хвилі. Довжину хвилі світлового потоку, що падає, змінюють шляхом почергового підключення світлодіодів різного кольору. Для зміни довжини світла, який падає на фотоопір, перемикач SA1 встановлюють у відповідні положення 5, 6, 7, 8, 9 (рис.1). Кожному положенню перемикача відповідає світлодіод певного кольору випромінювання. Середнє значення довжини хвилі світлодіодів пропонували студентам попередньо виміряти за допомогою монохроматора або використовуючи паспортні дані на прилади. У нашому випадку ми застосовували світлодіоди з довжинами хвиль: 460 нм; 520 нм; 580 нм; 700 нм; 820 нм. Для кожного значення довжини хвилі визначали залежність сили струму від прикладеної напруги. Дослідження проводили з фотоопорами, які опромінювалися і не опромінювалися потоком електронів. Результати представлені на рисунках 5 і 6.

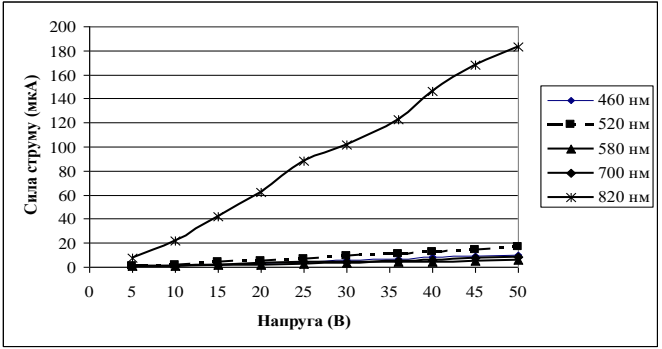

Рис. 5. Залежність сили струму від напруги та довжини хвилі (до опромінювання)

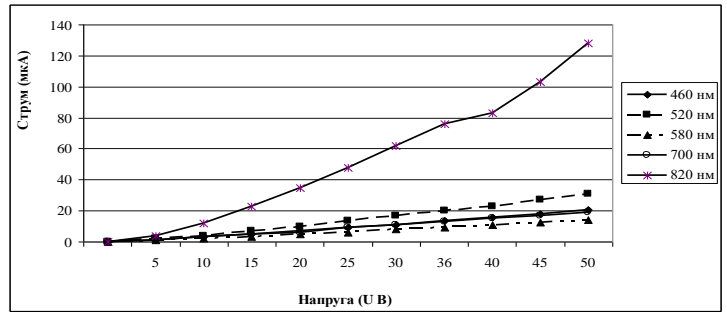

Рис. 6. Залежність сили струму від напруги та довжини хвилі (після опромінювання потоком електронів)

Дослідження показало: фотоопір, що досліджується, має максимальну чутливість в області червоного та інфрачервоного світла; опромінювання потоком електронів вливає на спектральні характеристики напівпровідника.

Спираючись на результати досліджень (рис. 5 і 6), студентам пропонували розрахувати провідність напівпровідника для двох випадків 
та побудувати графріки залежності провідності від довжини хвилі світла, яке падає (рис. 7).

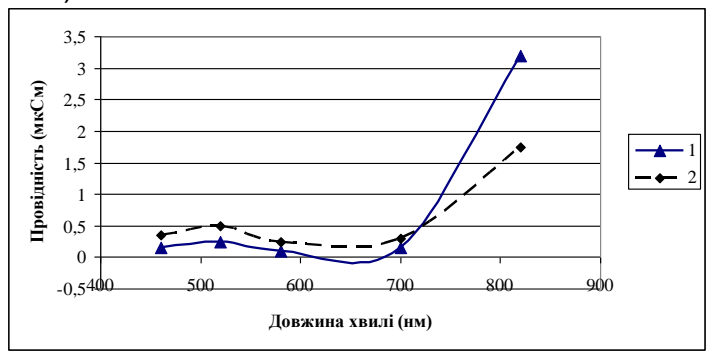

\section{Рис. 7. Залежність провідності від довжини хвилі}

(1 і 2 - до і після опромінювання зразка)

Аналізуючи результати дослідження, можна стверджувати, що опромінювання фотоопору потоком швидких електронів суттєво впливає на спектральну характеристику зразка. Використовуючи результати експерименту, студентам пропонували обчислити параметри: опір без освітлення; питому чутливість; інтегральну чутливість на ділянці, де $є$ лінійна залежність між фотострумом та прикладеною напругою (при

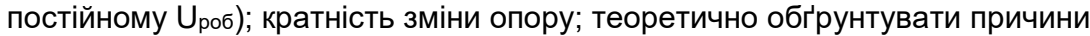
впливу зовнішніх факторів на характеристики фотоопору.

Висновки. Процес формування експериментальних навичок у майбутніх учителів фізики ми розглядаємо як комплексну проблему. Частково формування експериментальних навичок відбувається під час виконання лабораторних робіт згідно з робочими програмами курсу фізики. Наші дослідження показали що найбільш ефективним методом формування експериментальних навичок студентів $€$ спільна робота з викладачем при розв'язанні нестандартних творчих завдань, які мають практичне значення. Подальших досліджень потребує підвищення мотивації студентів-фрізиків перших курсів до експериментально-дослідницької діяльності та розробка лабораторних робіт з курсу фрізик з практичним змістом.

\section{Література}

1.Зикова К.М., Шишкін Г.О. Оцінка рівня навчально-пізнавальної активності учнів у процесі вивчення різних розділів курсу фрізики. Науковий часопис НПУ імені М.П. Драгоманова. Серія 5. Педагогічні науки: реалії та перспективи. - Вип. 60. Т. 1. : Київ : Вид-во НПУ ім. М.П. Драгоманова, 2018. - С. 174-177.

2.Пристрій для навчальних закладів для дослідження фотопровідності напівпровідників / Федоренко П.П., Шишкін Г.О., Скляр О.Г. Пат. № 24614 Україна. заявник і патентовласник Бердянський держ. пед.. ун-т., Таврійський держ. агр.. ун-т. - заяв. 23.07.2012; публік. 25.04.2013, Бюл. № 8.

3.Шишкін Г.О. Федоренко П.П. Лабораторний стенд для дослідження фотопровідності напівпровідників. Вісник Чернігівського національного педагогічного університету. Вип. 89. - Чернігів : ЧНПУ, - 2011. - С. 479-484.

4. Shyshkin G., Fedorenko P. Technique of experimental research of the mechanism of semiconductors photoconductivity. Temas actuales de la Fisica y la Ciencia de Materiales. Ed.: F. Perez Rodriguez, M. P. Sampedro, E. de L. Juarez Ruiz. Puebla, Mexico. 2013. - pp. 184-197. URL: http://www.ifuap.buap.mx/virtual/page vir.html 


\section{References}

1. Zykova K.M., Shyshkin H.O. Otsinka rivnia navchalno-piznavalnoi aktyvnosti uchniv u protsesi vyvchennia riznykh rozdiliv kursu fizyky. [Assessment of the level of educational and cognitive activity of students in the process of studying different sections of the course of physics]. Naukovyi chasopys natsionalnoho pedahohichnoho universytetu imeni M.P. Drahomanova. Seriia 5. Pedahohichni nauky: realii ta perspektyvy. Vypusk 60. Tom 1. : Kyiv : Vyd-vo NPU imeni M.P. Drahomanova, 2018. 174-177 [in Ukrainian].

2. Prystrii dlia navchalnykh zakladiv dlia doslidzhennia fotoprovidnosti napivprovidnykiv. [Device for educational institutions for the study of semiconductor photoconductivity] / Fedorenko P.P., Shyshkin H.O., Skliar O.H.Pat. № 24614 Ukraina. zaiavnyk i patentovlasnyk Berdianskyi derzh. ped.. un-t., Tavriiskyi derzh. ahr.. un-t. - zaiav. 23.07.2012; publik. 25.04.2013, Biul. № 8 [in Ukrainian].

3. Shyshkin H.O. Fedorenko P.P. Laboratornyi stend dlia doslidzhennia fotoprovidnosti napivprovidnykiv. [Laboratory stand for research of photoconductivity of semiconductors.]. Visnyk Chernihivskoho natsionalnoho pedahohichnoho universytetu. Vyp. 89. Chernihivskyi natsionalnyi pedahohichnyi universytet imeni T.H. Shevchenka; hol. red.. Nosko M.O. Chernihiv : ChNPU, 2011. 479-484 [in Ukrainian].

4. Shyshkin G., Fedorenko P. Technique of experimental research of the mechanism of semiconductors photoconductivity. Temas actuales de la Fisica y la Ciencia de Materiales. Ed.: F. Perez Rodriguez, M. P. Sampedro, E. de L. Juarez Ruiz. Puebla, Mexico. 2013. P. 184 - 197. [in English]

\section{АНОТАЦІЯ}

У статті наводиться опис проведення експериментального дослідження основних характеристик і параметрів напівпровідникових фротоопорів студентамифрізиками педагогічного університету. Дослідження проводилося на розробленому запатентованому та виготовленому нами лабораторному стенді. Одним з основних складників фрахової підготовки майбутніх учителів фрізики $є$ формування навичок організації та проведення фрізичного експерименту. Під час виконання навчального лабораторного експерименту студенти набувають нових знань; фрормують первині навички використання фрізичного обладнання та приладів; уміння планувати проведення експерименту та аналізувати результати. Проведені нами дослідження показали, що виконання студентами тільки лабораторних робіт за готовими інструкціям, ще не забезпечують належної підготовки до самостійного планування $і$ проведення експериментального дослідження. Підвищення якості підготовки студентів-фрізиків потребує вдосконалення фрорм і методів організації начального експерименту. Для часткового розв'язання иієї проблеми нами запропонована дослідна робота, яку можна проводити на заключному етапі підготовка фрахівия.

Метою статmі $\epsilon$ аналіз результатів проведеного дослідження характеристик фотоопору, котре було запропоновано студентам-фрізикам педагогічного університету. Експеримент включав: зняття вольт-амперних, світлових, спектральних та частотних характеристики фотоопорів; визначення інтегральної чутливості фотооопор; встановлення впливу зовнішніх фракторів на характеристики напівпровідників. Для дослідження використовували фотоопір на основі сірчистого кадмію. 3 метою виявлення впливу зовнішніх факторів на характеристики й параметри напівпровідників студентам пропонували дослідити фотоопір до і після обробки його робочої поверхні потоками швидких електронів $з$ максимальною енергією до 1,15 МеВ. Напівпровідник опромінювали електронами на промисловому прискорювача електронів. Залучення студентів до проведення експериментальної роботи, яка проводилася в позаудиторний час під керівництвом викладача, має вважливе значення у формуванні узагальнених навичок експериментальних досліджень майбутніх фрахівців.

Ключові слова: фрізичний експеримент, напівпровідник, фротоопір, властивості. 